\title{
QUEEN'S
UNIVERSITY
BELFAST
}

\section{From Counter-terrorism to Criminal Justice: Transformation or Business as Usual?}

Tomlinson, M. (2012). From Counter-terrorism to Criminal Justice: Transformation or Business as Usual? Howard Journal of Criminal Justice, 51(5), 442-457. https://doi.org/10.1111/j.1468-2311.2012.00735.x

\author{
Published in: \\ Howard Journal of Criminal Justice
}

\section{Document Version:}

Peer reviewed version

Queen's University Belfast - Research Portal:

Link to publication record in Queen's University Belfast Research Portal

\section{Publisher rights}

(c) 2012 The Author; The Howard Journal of Criminal Justice ( 2012 The Howard League and Blackwell Publishing Ltd. This work is made available online in accordance with the publisher's policies. Please refer to any applicable terms of use of the publisher.

\section{General rights}

Copyright for the publications made accessible via the Queen's University Belfast Research Portal is retained by the author(s) and / or other copyright owners and it is a condition of accessing these publications that users recognise and abide by the legal requirements associated with these rights.

Take down policy

The Research Portal is Queen's institutional repository that provides access to Queen's research output. Every effort has been made to ensure that content in the Research Portal does not infringe any person's rights, or applicable UK laws. If you discover content in the Research Portal that you believe breaches copyright or violates any law, please contact openaccess@qub.ac.uk. 


\title{
FROM COUNTER-TERRORISM TO CRIMINAL JUSTICE: TRANSFORMATION OR BUSINESS AS USUAL?
}

\author{
MIKE TOMLINSON
}

\author{
Professor of Social Policy, Queen's University Belfast
}

\begin{abstract}
:
The article explores the extent to which criminal justice in Northern Ireland has been reconstructed over the past fifteen years. The focus is on the framework provided in the Good Friday Agreement (1998) and the range of transition processes that followed. Post-Agreement Inquiries are reviewed and the findings demonstrate the institutional rigidities facing the transformation of criminal justice. While the ideologies and practices of counter-terrorism no longer dominate the business of criminal justice, the extent of change in terms of social representativeness, scale and expenditure is variable, with the prison service proving the least changed.
\end{abstract}

Key words: transitional justice, criminal justice, political economy

Introduction

Counter-terrorism as Industry

Until the 1998 Good Friday Agreement, the business of criminal justice in Northern Ireland was dominated by containing and countering violent political conflict. Vast resources were committed to this objective and a huge 'war economy' created. Policing, imprisonment and the courts were an integral part of this expansive security industry and have therefore faced major challenges during the transition to peace.

The purpose of this article is to review progress on the reconstruction of Northern Ireland's criminal justice institutions in the period following the 
Agreement, with a particular focus on barriers to change, the resourcing of change and the issue of social representation.

International experience demonstrates that if protracted conflicts are not to be repeated, complex and long-term processes of transformation are required across many spheres, including substantial reductions in conflictrelated industries and investment in social reconstruction (Collier et al. 2003; World Bank 2011). Human rights abuses, before and during cycles of conflict, are key sources of dispute and often dominate the politics of peace processes. In the case of Northern Ireland, such 'legacy' issues have received considerable attention within the paradigm of 'transitional justice' (e.g. Ní Aoláin 2002; Bell 2003; Campbell 2010). Policing has been at the heart of most of the significant legal and political disputes in the criminal justice field and to some extent remains so (O'Rawe 2003; Committee on the Administration of Justice 2011).

There have been three main criticisms of the transitional justice paradigm. According to McEvoy (2007: 425), it has been dominated by lawyers and forms of legalism that 'disconnect individuals and communities from any sense of sovereignty' over the issues involved. Secondly, Brewer (2010: 37, 206-7) criticizes the 'good governance' approach to peace comprising 'democratic political institutions, market economies and human rights law' - for ignoring the importance of 'sociological issues that are equally critical to the success of the transition process'. The restoration of social bonds through 'hoping, forgiving, apologising, remembrance', truth 
recovery and healing, is essential in strengthening fragile peace processes. A third criticism invokes a broader notion of sociological concerns, focusing on the social needs and interests of those communities most affected by violent conflict. As Greiff and Duthie (2009) argue, the transitional justice approach tends to ignore the claims of social justice arising from the economic roots and consequences of conflict. Post-conflict economic development is often based on policies of economic liberalisation to the detriment of equality, social inclusion and cohesion (Hillyard et al. 2005; Oslen et al. 2010). In the Northern Ireland case, the question of resourcing transition has become more acute in the wake of austerity state budgeting and the devolution of justice achieved in April 2010 (Tomlinson and Kelly 2011).

The analysis below is informed by Christie's (1993) perspective on 'crime control as industry'. As with crime, a specialist global counter-terrorism industry has developed based on similar imperatives of social and political polarisation. Counter-terrorism is propelled by 'an urge for expansion (which) is built into industrial thinking' (1993: 13). It has also become 'normalised' in law, with attendant social and political effects (Sim and Thomas 1983; Hillyard 1993; Mathiesen 2002). For the Northern Ireland conflict, the early 1990s may be regarded as the 'high-point' of criminal-justice-as-counterterrorism in terms of the scale of resources involved, and a low-point in terms of legitimacy. There was little agreement at Westminster on the causes of conflict, how to police it effectively and how to move forward politically, especially on the sensitive issue of talking to terrorists. ${ }^{1}$ 
In the quest for the total elimination of terrorism the Government had almost doubled Northern Ireland's security expenditure (in real terms) in the ten years from 1984, adopting a 'blank cheque' mentality to the war on terrorism. Few had ever considered the costs of the conflict in financial terms or analysed the impact on the economy and labour market. According to Tony Benn, however, 'the cost of the war has been $£ 14.5$ billion' (HC Debate 1993, 230 , col. 515). Arguably, a more realistic total was $£ 23.5$ billion, with annual costs running to $£ 2.3$ billion by $1993 / 4$, and 42 per cent of the costs arising in Britain and the Republic of Ireland (Tomlinson, 1994: 25-32). More conventionally stated, public spending on Law, Order and Protective Services amounted to about 11 per cent of the public spending attributable to Northern Ireland at this time.

By the early 1990 s, more than 38,000 people were directly employed in policing, running the prisons and in the Ulster Defence Regiment. This was a segregated labour force - mainly male and Protestant - in a heavily segmented Northern Irish labour market (Rowthorn and Wayne 1988). The prospect of armed republicanism leaving the stage as part of a peace process represented a huge threat to the security industry. This is why the leader of the Ulster Unionist Party, Jim Molyneaux, saw the IRA's 1994 ceasefire as 'destabilising' and the worst thing that had ever happened to unionists (McKittrick 1999). There were good reasons not to trust the old enemy, to seek out opportunities to re-create it, and to resist the potential transformation of Northern Ireland's criminal justice agencies. 


\section{Criminal Justice in Transition}

The 1998 Agreement provided the broad template for the reconstruction of criminal justice in the context of new constitutional relationships between Northern Ireland, Great Britain and the Republic of Ireland. The notion of 'national security', used to justify so many areas of counter-terrorist policy and practice in the past, now appeared at odds with the recognition of both British and Irish identities. By incorporating the principle of the right to self-determination of the people on the island of Ireland to bring about a united Ireland, the 1998 Agreement set in train a whole series of transformative possibilities in how justice is done and seen to be done in Northern Ireland, and to a lesser extent in the Republic (Vaughan and Kilcommins 2008).

The Agreement signalled root and branch reform of policing, the prosecution process, and judicial appointments, emphasising human rights and accountability within criminal justice agencies. Underlying the transition from war to peace was the emphasis on demilitarisation. This meant the decommissioning of weapons and explosives belonging to the armed groups as well as the 'normalisation of security arrangements and practices' (Good Friday Agreement 1998: para. 8.1). An Independent International Commission on Decommissioning was established (August 1997) under parallel Irish and UK legislation, and parties to the Agreement pledged 'to use any influence they may have, to achieve the decommissioning of all paramilitary arms within two years' (Good Friday Agreement 1998: para. 7.3). 
A further requirement of successful transition was to address 'Reconciliation and Victims of Violence'. The Agreement anticipated the report of the Northern Ireland Victims Commission set up in October 1997 to explore ways 'to recognise the pain and suffering felt by victims of violence ... including those who have died or been injured in the service of the community' (Bloomfield Report 1998: 8). While the Commission's work mainly focused on the psychological needs of victims, it also made recommendations on how reconciliation between the communities might be achieved. The demands for 'truth and justice' in relation to state killings and collusion between intelligence agencies, security forces and Loyalist armed groups was mentioned briefly, but no recommendation was made as to whether or how this issue should be addressed (Bell 2003: 1103).

In 2001, the Irish and British Governments appointed Peter Cory, a retired Canadian Supreme Court Judge, to look at six cases in which allegations of collusion had become major political issues affecting the implementation of the Agreement and confidence in the peace process as a whole. Of particular concern to Unionists was alleged collusion between the IRA and An Garda Síochána over two incidents in the border area in the late 1980s. One case involved the killing of two Royal Ulster Constabulary officers (Breen and Buchanan) while the other concerned Lord Justice Gibson and his wife. In the Gibson case Cory found there was no basis for recommending a public inquiry but in the Breen/Buchanan case, there was 'evidence capable 
of constituting collusion' (Cory 2003b: para. 2.168). The Irish Government therefore established the Smithwick Tribunal (2005) which began public hearings in June 2011. Cory recommended four other inquiries into collusion - over the killings of Rosemary Nelson, Pat Finucane, Billy Wright and Robert Hamill. $^{2}$ Taken together, the cases raised fundamental issues about the nature and operation of a criminal justice system driven by counter-terrorist objectives within a politically polarised society.

The killing of Billy Wright involved allegations of collusion by prison authorities, given that he was murdered in $\mathrm{H}$ Block 6 of the Maze Prison. In recommending a public inquiry, Cory (2004c) identified nine potentially collusive acts by the prison authorities, which together merited a public inquiry. The Inquiry report was highly critical of a range of agencies: the Prison Service, the Northern Ireland Office, the Ministry of Defence, the RUC and its successor, the Police Service of Northern Ireland (PSNI), and the Security Service (MI5). The criticisms referred in particular to poor management, from the Chief Executive downwards, poor record keeping, the failure to produce documentary evidence in a timely fashion, and to the destruction of 'a large number of documents' before the start of the Inquiry (MacLean Report 2010: 651).

Two of the cases examined by Judge Cory concerned Catholic solicitors, Rosemary Nelson and Pat Finucane. Rosemary Nelson represented the residents of Garvaghy Road, Portadown, who were trying to stop the Orange Order ${ }^{3}$ marching through their area from Drumcree Church. ${ }^{4}$ She also represented the Hamill family in proceedings arising from the killing 
of Robert Hamill. Cory was in no doubt that, 'it was the work of Rosemary Nelson as a solicitor which led to her murder' (Cory Report 2004d: para. 4.10) and thus called for a public inquiry. The Government was implicated in collusion as the Northern Ireland Office had turned a blind eye to death threats against Nelson of which it was well aware (Cory Report 2004d: 4.241). The public inquiry (published May 2011) concluded that the Northern Ireland Office and RUC management were negligent in a number of respects and that overall 'the state failed to take reasonable and proportionate steps to safeguard the life of Rosemary Nelson' (Moreland Report 2011: 466).

Pat Finucane represented a number of high profile republicans, including hunger striker Bobby Sands MP, and his clients were often told by RUC interrogators that their solicitor was targeted. Nelson and Finucane were not unusual in this respect. RUC threats against lawyers involved in criminal cases were common in the 1980s and 1990s. Some of these lawyers were apparently resented for being successful Catholics, were assumed to be 'fellow-travellers' of their paramilitary clients and were subject to speculation that their high earnings from legal aid were financing terrorist causes (Murphy 2000: 1889-91). Such stereotyping was famously reinforced by a Home Office Minister, Douglas Hogg, who told the House of Commons (1 $17^{\text {th }}$ January 1989) that 'there are in Northern Ireland a number of solicitors who are unduly sympathetic to the cause of the IRA', an opinion that could only have come from his earlier meeting with the RUC (Cumaraswamy 2009: 58). Finucane was shot dead while having Sunday lunch less than a month later $\left(12^{\text {th }}\right.$ February, 1989). 
Finucane was not only known within the RUC for 'his pioneering efforts in bringing successful civil claims for assault and false imprisonment against the police' (Moore 2009), but was also in the public eye for his legal successes in relation to one of the 'shoot-to-kill' cases (Treacy 2009). By the early 1980s, Finucane had become 'a thorn in the side of those in the military and security establishment who had things to hide' (Rolston 2000: 176).

The issues surrounding the killing of Pat Finucane are constitutionally and legally so serious, and so contested, that they remain unresolved. According to one account,

'there is evidence that certain members of the British government knew exactly what was going on at that time in Northern Ireland because of the constant stream of totally reliable information forwarded to both the Joint Intelligence Committee and the Home Office by their officers working and serving in the intelligence agencies ...' (Davies 1999: 135).

Judge Cory's review of the Finucane case relied heavily on the work of John Stevens who carried out three inquiries over a fourteen-year period into allegations of collusion between various security forces and Loyalist armed groups, from the period 1987 to 1989. In 2003, an overview of Stevens' findings to date was published which indicated that 'some major lines of enquiry are still in the early stages of investigation' (Stevens Report 2003: 3). Part of the Stevens Report describes a culture of obstruction 'widespread within parts of the Army and the RUC' which included setting fire to his incident room (2003: 13). ${ }^{5}$ Stevens concluded that the murders of Patrick Finucane and Brian Adam Lambert could have been prevented'. He went on,

'I conclude there was collusion in both murders and the circumstances surrounding them... [ranging from] the willful failure to keep records, the 
absence of accountability, the withholding of intelligence and evidence, through to the extreme of agents being involved in murder'.

It is clear from the evidence available to Cory that the Security Service was informed on at least three occasions by its sources that Loyalists planned to assassinate Finucane. Cory found evidence that 'an officer of the joint Security Service/Secret Intelligence Service' described the 1981 Special Branch decision not to alert Finucane as "courageous" (Cory Report 2004a: 60-1). This was an indication that,

'both the Security Service and RUC SB saw agent security as taking precedence over the need to warn a targeted individual that his life was at risk'. (Cory Report 2004a: 62)

On the basis of 'strong evidence that collusive acts were committed by the Army (FRU), the RUC SB and the Security Service', Cory was satisfied of the need for a public inquiry (Cory Report 2004a: 107). Following publication of the Cory Report, the Finucane family was told by the Blair Government that an inquiry must await new legislation - the Inquiries Act, 2005, which empowers Government Ministers to restrict attendance at an inquiry and the disclosure or publication of evidence (Section 19, Inquiries Act 2005). The family refused to participate in an inquiry convened under the Act, in the absence of assurances that an inquiry Chair would have full powers of independence and compulsion, following the model applied to the public inquiry into the death of Baha Mousa. ${ }^{6}$ In October 2011, the Finucane family were invited to Downing Street, expecting an Inquiry to be agreed on this basis. Instead, Prime Minister David Cameron told the family that the longstanding commitment to a public inquiry was now withdrawn. His alternative was to appoint Sir Desmond de Silva QC to review all the papers relating to 
the Finucane murder, a decision that the family is challenging through judicial review.

In 1994 Geraldine Finucane took the UK Government to the European Court of Human Rights (ECtHR) on the grounds that there had been no proper, effective investigation into her husband's death. The Court eventually found in her favour in 2003 , a politically troublesome outcome given the large number of outstanding lethal force cases from Northern Ireland at that time (Ní Aoláin 2002). In particular, the ECtHR cases raised issues of the lack of independence in the investigation of deaths caused by police officers, the failure of the Director of Public Prosecutions to explain decisions whether to prosecute or not, and the failure of the inquest system to provide a prompt and effective remedy. While the ECtHR cases stimulated reform in these areas, the lethal force deaths 'represent an enormous accountability gap for the State' (Ní Aoláin 2002: 582).

The ECtHR judgements were undoubtedly a factor in the 2005 decision to establish an Historical Enquiries Team (HET) within PSNI to review 'unresolved' killings arising from the conflict between 1968 and 1998. The police eventually agreed to review 3,268 cases, over 2,000 of which were regarded as unsolved murders (Lundy 2009). Some of these are 'complex cases' involving linked killings and collusion. The initiative has improved communication with the families of those killed, the majority of whom were never given any information about the death itself or any investigation that may have taken place (Consultative Group on the Past 2009: 107). There 
remain different views as to whether HET investigations play a role in satisfying the requirements of Article 2 of ECHR or fall short of this standard.

HET cases involving complaints against the police (over 120 thus far) are referred to the Office of the Police Ombudsman (OPONI) and the handling of these cases has proved particularly controversial, resulting ultimately in the resignation of the Police Ombudsman. The main problems have been 'the length of time taken, the quality of the reports it (OPONI) has published, and the conclusions reached' (Committee on the Administration of Justice 2011: 16). A Criminal Justice Inspection Report (2011: 34) concluded that the flawed nature of the investigation process in historic cases, the divisions within senior management, and concerns around the handling of sensitive material have undermined confidence in the work of the OPONI among some staff and key stakeholders'. It recommended the suspension of all work on historical cases until an adequately resourced Directorate becomes fully operational.

It is clear from the above that the intelligence-led policing practices which allowed people to commit murder with impunity remain a significant source of political contention. As such they present barriers to the building of confidence in the PSNI and the implementation of the policing principles articulated in the Agreement and the Patten Report: representative bodies serving communities by preventing crime and solving problems within a framework of accountability and human rights. 


\section{The Costs of Transition}

The piecemeal nature of the transitional processes reviewed above owes much to the lack of political agreement over the causes of the violent conflict and the reasons why it endured so long. While there is no 'transitional justice budget' as such, it is possible to identify most of the major costs of transitional processes (Table 1). It should be pointed out that Table 1 does not include the costs of the Stevens Enquiry (ongoing) or the twenty other major inquiries in Northern Ireland held since 1968, most of which have concerned the legitimacy of police, military and intelligence operations (Rolston and Scraton 2005: 552). It also excludes the costs of implementing the Patten Report. Table 1 shows that over $£ 440$ million has been spent on recent transitional justice process in the North and $€ 68$ million in the South to date.

Table 1: Identifiable costs of transitional justice processes

\begin{tabular}{|l|c|l|}
\hline \multicolumn{1}{|c|}{ Activity } & $\begin{array}{c}\text { Budget } \\
\text { (£ millions) }\end{array}$ & \multicolumn{1}{|c|}{ Notes } \\
\hline Northern Ireland & 6.2 & $\begin{array}{l}\text { Source: Twenty-Sixth and Final Report } \\
\text { of the Independent Monitoring } \\
\text { Commission, 2004-2011 - Changes, } \\
\text { Impact and Lessons. }\end{array}$ \\
\hline $\begin{array}{l}\text { Independent } \\
\text { Monitoring } \\
\begin{array}{l}\text { Commission } \\
\text { (Decommissioning) }\end{array}\end{array}$ & 18.3 & $\begin{array}{l}\text { Funding for victims' groups 1998-2001. } \\
\text { Source: Commons Hansard, 4 } \\
\text { February 2002, col. 652WA. }\end{array}$ \\
\hline $\begin{array}{l}\text { Bloomfield Report } \\
\text { Post-May 2007 victims } \\
\text { funding }\end{array}$ & 36.0 & $\begin{array}{l}\text { Northern Ireland Assembly, 26 } \\
\text { February 2010, WA 208. }\end{array}$ \\
\hline $\begin{array}{l}\text { Support for security } \\
\text { forces }\end{array}$ & 13.3 & $\begin{array}{l}\text { Includes George Cross Foundation, } \\
\text { Police Rehabilitation and Retraining } \\
\text { Trust, Police widows' fund }\end{array}$ \\
\hline $\begin{array}{l}\text { Ex-prisoner support } \\
\text { groups }\end{array}$ & 17.3 & $\begin{array}{l}\text { 1999-2003. Source: House of Lords } \\
\text { Hansard, 10 June 2004, col. 37WA. }\end{array}$ \\
\hline
\end{tabular}




\begin{tabular}{|c|c|c|}
\hline $\begin{array}{l}\text { The Bloody Sunday } \\
\text { Inquiry }\end{array}$ & 192.0 & Source 2. \\
\hline Robert Hamill Inquiry & 33.0 & Source 2. \\
\hline Billy Wright Inquiry & 30.6 & Source 2. \\
\hline $\begin{array}{l}\text { Rosemary Nelson } \\
\text { Inquiry }\end{array}$ & 46.5 & Source 2. \\
\hline Pat Finucane Inquiry & & $\begin{array}{l}\text { Government will take account of } \\
\text { potential duration and cost of an } \\
\text { inquiry. Source: House of Lords } \\
\text { Hansard, } 15^{\text {th }} \text { June } 2011 \text {, col. 198WA. } \\
\text { De Silva Review not costed. }\end{array}$ \\
\hline $\begin{array}{l}\text { Historical Enquiries } \\
\text { Team }\end{array}$ & 34.0 & \\
\hline $\begin{array}{l}\text { Police Ombudsman } \\
\text { HET work }\end{array}$ & 4.3 & Source 1. \\
\hline $\begin{array}{l}\text { Retrospective Murder } \\
\text { Investigation Unit }\end{array}$ & 7.5 & Source 1. \\
\hline $\begin{array}{l}\text { Consultative Group on } \\
\text { the Past }\end{array}$ & 1.3 & $\begin{array}{l}\text { Source: Commons Hansard, Written } \\
\text { Answers, } 11 \text { February 2009, col. } \\
2020 \text { W }\end{array}$ \\
\hline (Legacy Commission) & $(300.0)$ & $\begin{array}{l}\text { Proposed. Would absorb any future } \\
\text { HET costs. }\end{array}$ \\
\hline Delayed Inquests & 0.4 & $\begin{array}{l}26 \text { cases involving } 36 \text { deaths are } \\
\text { subject to delayed inquests. The oldest } \\
\text { case is from } 1972,3 \text { are from the } \\
1980 \text { s, } 15 \text { from the } 1990 \text { s, and } 6 \text { from } \\
\text { the } 2000 \text { s. Source } 1 .\end{array}$ \\
\hline $\begin{array}{l}\text { Independent } \\
\text { Commission for the } \\
\text { Location of Victims' } \\
\text { Remains }\end{array}$ & & $\begin{array}{l}\text { Costs shared on a North/South basis } \\
\text { as they arise. }\end{array}$ \\
\hline Republic of Ireland & \multicolumn{2}{|c|}{ (Euros millions) } \\
\hline Barron Inquiries & 2.3 & $\begin{array}{l}\text { Dáil Eireann Debates, } 26 \text { October } \\
2005 .\end{array}$ \\
\hline $\begin{array}{l}\text { Commission of Inquiry } \\
\text { into Dublin and }\end{array}$ & 0.8 & $\begin{array}{l}\text { The Irish Independent, } 28 \text { August } \\
2006 \text {. }\end{array}$ \\
\hline
\end{tabular}




\begin{tabular}{|l|c|l|}
\hline Monaghan Bombings & & \\
\hline Smithwick Tribunal & 0.3 & $\begin{array}{l}\text { This concerned alleged Garda } \\
\text { collusion in the killings of Breen and } \\
\text { Buchanan. Dáil Éireann, Written } \\
\text { Answers, 16 February 2006. }\end{array}$ \\
\hline Morris Tribunal & 58.0 & \\
\hline Remembrance Fund & 6.2 & $\begin{array}{l}\text { Seanad Éireann Debates Vol.188, 20 } \\
\text { February 2008, col. 984. }\end{array}$ \\
\hline
\end{tabular}

Source 1: Healing Through Remembering http://www.healingthroughremembering.org/ Source 2: Sear (2011).

The muted arguments about the costs of inquiries North and South became louder as the Bloody Sunday costs increased. Indeed, it has been argued that this was the main factor behind the introduction of the new Inquiries Act (Robins 2010). When calling for an inquiry in the Finucane case, Judge Cory argued that Inquiries are 'a small price to pay for a lasting peace' (Cory Report 2004a: 111). As one Senior Counsel put it when discussing the Barron Report,

'How can one build peace if one does not know the truth about the past? [...] How much money is there for making peace? There seems to be any amount of money for making war'. (Ó Dúlacháin 2004)

\section{Towards Representative Criminal Justice}

The Good Friday Agreement promised a 'new beginning' to policing and included terms of reference for the Patten Commission. One section of the Patten Report dealt with size, noting that the RUC had 13,000 uniformed officers and 3,000 civilian staff. According to the Home Office model, Northern Ireland should have 4,300 officers and 1,700 civilians (Patten 
Report 1999: 75). The Patten plan was to reduce numbers to around 7,500 full-time regular officers and 2,500 part-timers as a reserve.

The community background of police officers was a major political concern as the Agreement aspired to a police service that was socially representative. Patten noted that the RUC was overwhelmingly Protestant and male. Only 8 per cent of full-time officers were Catholic overall, with a lower figure for the full-time Reserve. While the figure for women was slightly better at 12.6 per cent, a third of female officers were in the Part-Time Reserve. As regards civilian support staff, the picture was very different for women (66 per cent of the total) but not so different for Catholics (12 per cent of the total) (Patten Report 1999: 82, 85).

Patten proposed that the appointment of police officers should be made on a 50:50 Catholic/Protestant basis, for both civilian and uniformed personnel, drawn from a pool of recruits who had achieved a defined standard in the recruitment process. Anticipating that this would be opposed, Patten proposed that it should be temporary and subject to review after ten years. With 50:50 recruitment and other measures in place, the Patten Report predicted that Catholics would comprise between 28 and 33 per cent of the police service within ten years (Patten Report 1999: 83). No targets were set for the recruitment of women.

The proportion of Catholic uniformed officers in the PSNI had reached 30.3 per cent and the proportion of women, 26.6 per cent, by April 2011. The 
picture for civilian staff was not so close to the Patten target: 18.7 per cent were Catholic and 36 per cent male. The Government's view is that 'the PSNI is now broadly reflective of the community' (Northern Ireland Office 2010a: 5) and thus feels that 'the use of the provisions beyond March 2011 cannot be justified' (Northern Ireland Office 2010a: 13).

In Northern Ireland as a whole, Catholics make up 45.5 per cent of fulltime employees in the public sector (Equality Commission 2010). Of all monitored applicants in the workforce in 2009, Catholics made up 51 percent of the total. The figure for appointees was 50.9 per cent. The Catholic applicant figures for the PSNI are considerably below this and, for any specific recruitment campaign, reflect the political conditions pertaining at the time. There has been a five-fold increase in bombing incidents since 2006/07 (Chief Constable 2011: 54) and groups opposed to the peace process have sought to deter Catholics from membership of the PSNI by attacking Catholic police officers. ${ }^{7}$

In the last ten years there have been sixteen recruitment campaigns and more than 107,000 people have applied to join the police (Northern Ireland Office 2010a: 17). The proportion of Catholic applicants began to rise as political agreement on devolution progressed in 2006 and early 2007 . The June 2007 recruitment attracted the highest proportion of Catholics ever (44.3 per cent) but the figure has declined in each subsequent recruitment exercise (to 37.4 , January 2010). In the absence of detailed monitoring data it is not possible to predict the impact of the withdrawal of 50:50 recruitment, but there 
have been concerns that the proportion of Catholics qualifying for the merit pool is well below the proportion of Catholic applicants (Criminal Justice Inspection 2009: 35-36). After a perfunctory consultation, the Government allowed the $50: 50$ provision to lapse.

The main downsizing target in the Patten Report of 7,500 full-time officers was met some time ago. Arguably, the police service remains disproportionately large relative to recorded crime, detection rates and comparisons with Britain. Policing Northern Ireland cost $£ 1.2$ billion in 2010/11 for an overall recorded crime rate of 58 per 1,000 population, representing a cost of $£ 41,300$ for each crime detected. The average crime rate across Britain was 79 for 2009/10 (HC Debate, 527, col. 1105-6W).

No Patten-style review of the prison system was built into the Agreement. All the focus was on the release of prisoners serving sentences for offences scheduled under Northern Ireland's emergency powers. These were effectively superseded by the normalisation of anti-terrorist legislation in 2000 as proposed in the Lloyd Report 1996 (Thomas 2003).

The business of prisons in Northern Ireland has changed very little since the 1998 Agreement. Although there are now relatively few prisoners belonging to groups continuing to use violence, the Prison Service remains steeped in a legacy of conflict. With a total staff of 2,300 and a budget of $£ 157$ million, the cost per prisoner is $£ 77,800$ or $£ 95,000$ based on occupancy (Criminal Justice Inspection 2010: 5), almost the same as in 1993. In the 
words of the Criminal Justice Inspection (2010: vii), the Prison Service 'has remained largely untouched by the reforms of the criminal justice system'. But there has been growing pressure to reduce costs and to address the unrepresentative composition of the prison workforce. As of April 2010, only 10 per cent of the 1,860 uniformed prison staff were from a Catholic background (Prison Service 2010). Female officers are 22 per cent of the total.

In a damning review of the Prison Service, the Owers Report complained that change is limited by 'longstanding issues of culture, staffing and governance which have been managed round, rather than tackled headon' (Owers Report 2011: 6). The Prison Officers' Association is identified as resisting and delaying change at every opportunity, invoking frequent 'workto-rule' actions. Now justice is a devolved responsibility, the Report argues that transformational change needs to be driven by a cross-party commitment to use prisons expenditure effectively. The alternative is to raise the possibility of a strengthened role for the private sector' (Owers Report 2011: 7). To date the prison reform issue attracting the most attention is the prospect of removing royal insignia and titles from the Prison Service. First Minister Peter Robinson has threatened to resign over the issue.

The Agreement contained a commitment to a wide-ranging review of criminal justice including judicial appointments, the prosecution process, cross-border co-operation and the possibility of a Department of Justice (Criminal Justice Review Group 2000). This review was very much an in- 
house exercise as compared with the internationally high profile Patten review. It produced 294 recommendations, many of which modernised or endorsed current practices and arrangements, or recommended further discussion. All of this was framed within a conventional review of the extent of crime, fear of crime and surveys of public opinion on sentencing, young offenders, the police and willingness to report crime.

The significant changes were structural rather than cultural, though there was an emphasis on human rights training, accountability and transparency. The Review supported restorative justice for juveniles and young adults, proposed the setting up of a judicial appointments commission, and recommended the establishment of a new prosecution service. It was proposed that the inside of courts should be free of any symbols, that the judicial oath should be neutralised and that the declaration of 'God Save the Queen' on entry to court of the judiciary should cease.

In terms of budget and personnel, the Court Service, the Youth Justice Agency and the Public Prosecution Service (established in 2006) are dwarfed by policing and prisons. For example, Northern Ireland spends 60 times as much on the police service as it does on the Youth Justice Agency (£20m). The Courts Service, which employs 770 people, has a budget of $£ 55 \mathrm{~m}$. The new Public Prosecution Service is about 70 per cent the size of the Courts Service. Both the Courts Service and the Public Prosecution Service are much more representative of the labour market than the prison and police 
services, with 38 and 50 per cent respectively of their employees drawn from the Catholic community.

\section{Conclusion}

This overview of change in Northern Ireland's criminal justice institutions has focused both on the scale of the industry and the nature of the institutions. In characterising the 'blank-cheque' approach to security-based, counter-terrorist institutions in the past, many highly politicised issues arise regarding policing cultures and, importantly, the defence of past practices through strategies of denial, obsfucation and contestation by the agencies themselves, sometimes with and sometimes without government support from Britain or Ireland. The conflict itself generated many controversies over human rights standards and profound divisions over the very idea of justice. In some cases, fundamental constitutional issues about governance and the rule of law have arisen where it appears that strategies of informant and agent protection are more important than life protection, and where responsibility lies with the highest levels of government.

The legacy of conflict and associated repositories of power are, however, deeply embedded. Change within the institutions of criminal justice has at times been accelerated by transitional processes, as in the case of inquiries into pre-1998 killings, ECHR Article 2 compliance and the development of a more appreciative approach to the relatives of those killed in the conflict. At other times those processes have revealed deep 
institutional and political rigidities, especially in the area of prisons, record keeping and intelligence. Transitional mechanisms and events have arisen unpredictably and in a piecemeal fashion, driven by a combination of the politics of the devolution, the needs of victims and survivors, struggles for truth and justice, and state-managed reforms, such as policing. With no agreed meta-narrative to account for the conflict and its persistence, it is inevitable that the transformation of criminal justice is patchy, contested and characterised by stalled initiatives such as the call for a Legacy Commission made two years ago. Ultimately, transitional justice has benefited lawyers more than the communities most damaged by the conflict.

While political energies have been focused on transition, and particularly the transformation of policing, the more routine business of criminal justice has been less of a democratic priority. As recorded crime falls, the Northern Ireland prison population rises back up to 80 per cent of wartime levels. The criminal justice industry as a whole though has contracted by about one-third in employment terms over the last decade and is now 8 per cent of total public spending on Northern Ireland. The criminal justice workforce is now more representative of the Catholic population even though the prison system remains unreconstructed and will need a radical programme of early retirement and recruitment to achieve a more representative workforce. The industry may contract further, particularly in the prison sector where the budget is heading for a 28 per cent cut in cash terms over the next three years, offset to an extent by the extra security-related 
$£ 245 \mathrm{~m}$ allocation to PSNI over the next four years. Whether these overall budgetary pressures and the creation of the Department of Justice for Northern Ireland will invigorate public debate on the fundamental purpose and value of criminal justice remains to be seen.

\section{References}

Ní Aoláin, F. (2002) 'Truth telling, accountability and the right to life in Northern Ireland', European Human Rights Law Review, 5, 572-590.

Amnesty International (1994) Political Killings in Northern Ireland, London: Amnesty International.

Barron Report (2003) Interim Report on the Report of the Independent Commission of Inquiry into the Dublin and Monaghan Bombings, Joint Committee on Justice, Equality, Defence and Women's Rights, Houses of the Oireachtas, Dublin.

Bell, C. (2003) 'Dealing with the Past in Northern Itreland', Fordham International Law Journal, 26: 1095-1147.

Bloomfield Report (1998) We Will Remember Them. Report of the Northern Ireland Victims Commissioner, Belfast: Stationery Office.

Brewer, J. D. (2010) Peace Processes: A Sociological Approach, Cambridge: Polity Press.

British Transport Police (1994) Annual Report 1993-4, London: HMSO.

Campbell, C. (2010) 'The Spectre Returns: Conflicted Democracies, Truth Commissions and the Law', Web Journal of Current Legal Issues, 1. pp. 112. 
Chief Constable (2011), Annual Report of the Chief Constable 2010-11, Belfast: Police Service of Northern Ireland.

Christie, N. (1993) Crime Control as Industry: Towards GULAGS, Western Style, London: Routledge (second edition).

Committee on the Administration of Justice (2011) Human Rights and Dealing with Historic Cases - A Review of the Office of the Police Ombudsman for Northern Ireland, Belfast: CAJ.

Consultative Group on the Past (2009) Report of the Consultative Group on the Past, Belfast.

Collier, P. et al. (2003) Breaking the Conflict Trap: Civil War and Development Policy, Oxford: Oxford University Press/World Bank.

Cory Report (2003a) Cory Collusion Inquiry Report Lord Justice Gibson and Lady Gibson, http://www.patfinucanecentre.org/cory/gibson.pdf

Cory Report (2003b) Cory Collusion Inquiry Report Superintendent Breen and Superintendent

Buchanan, http://www.patfinucanecentre.org/cory/breenbuchanan.pdf

Cory Report (2004a) Cory Collusion Inquiry Report, Patrick Finucane, House of Commons Paper 470, London: Stationery Office.

Cory Report (2004b) Cory Collusion Inquiry Report, Robert Hamill, House of Commons Paper 471, London: Stationery Office.

Cory Report (2004c) Cory Collusion Inquiry Report, Billy Wright, House of Commons Paper 472, London: Stationery Office.

Cory Report (2004d) Cory Collusion Inquiry Report, Rosemary Nelson, House of Commons Paper 473, London: Stationery Office. 
Criminal Justice Inspection (2009) Section 75: The Impact of Section 75 of the Northern Ireland Act 1998 on the Criminal Justice System in Northern Ireland, Belfast: Criminal Justice Inspection Northern Ireland.

Criminal Justice Inspection (2010) Northern Ireland Prison Service Corporate Governance Arrangements, Belfast: Criminal Justice Inspection Northern Ireland.

Criminal Justice Inspection (2011) An inspection into the independence of the Office of the Police Ombudsman for Northern Ireland, Belfast: CJINI.

Criminal Justice Review Group (2000) Review of the Criminal Justice Sytem in Northern Ireland, Norwich: HMSO.

Cumaraswamy, D. (2009) Patrick Finucane: His Life and His Legacy, 58-60, London: British and Irish Human Rights Watch. http://www.birw.org/

Davies, N. (1999) Ten-Thirty-Three: The Inside Story of Britain's Secret Killing Machine in Northern Ireland, Edinburgh: Mainstream Publishing.

Equality Commission (2010) Fair Employment Monitoring Report No. 20 (2009), Belfast: Equality Commission for Northern Ireland.

Gage Report (2011) The Baha Mousa Public Inquiry Report (three volumes) HC 1452-I-III, London: Stationery Office.

Garvaghy Residents (1999) Garvaghy: A Community under Siege, Belfast: Beyond the Pale Publications.

Good Friday Agreement (1998) Agreement reached in the multi-party negotiations. Belfast/Dublin: British//rish Governments.

Greiff, P. and Duthie, R. (Eds.) (2009) Transitional Justice and Development: Making Connections, New York: Social Science Research Council. Hillyard, P. (1993) Suspect Community, London: Pluto Press. 
Hillyard, P., Rolston, B. and Tomlinson, M. (2005) Poverty and Conflict in Ireland: An International Perspective, Dublin: Institute of Public Administration/Combat Poverty Agency.

Joint Committee Report (2004) Final Report on the Report of the Independent Commission of Inquiry into the Dublin and Monaghan Bombings. Dublin: Joint Oireachtas Committee on Justice, Equality, Defence and Women's Rights.

Lloyd Report (1996) Inquiry into Legislation Against Terrorism, Cm. 3420, London: HMSO.

Lundy, P. (2009) 'Can the Past be Policed? Lessons from the Historical Enquiries Team', Law and Social Challenges, 11, Spring/Summer.

Lundy, P. (2011) 'Paradoxes and Challenges of Transitional Justice at the "Local" Level: Historical Enquiries in Northern Ireland', Contemporary Social Science 6(1): 89-106.

MacLean Report (2010) The Billy Wright Inquiry - Report, HC 431, Session 2009/10, London: Stationery Office.

Mathiesen, T. (2002) 'Expanding the Concept of Terrorism', in P. Scraton (Ed.) Beyond September 11 $1^{\text {th }}$ : An Anthology of Dissent, London: Pluto Press.

McKittrick, D. (1999) 'A Trip into the Tortured Unionist Mind', The Independent, $10^{\text {th }}$ July.

McEntee Report (2007) Commission of Investigation into the Dublin and Monaghan Bombings of 1974, Final Report, available at: http://www.dublinmonaghanbombings.org/ 
McEvoy, K. (2007) 'Beyond Legalism: Towards a Thicker Understanding of Transitional Justice', Journal of Law and Society, 34(4), 411-440.

Moore, J. (2009) Patrick Finucane: His Life and His Legacy, 8-9, London: British and Irish Human Rights Watch. http://www.birw.org/

Moreland Report (2011) The Rosemary Nelson Inquiry Report, HC 947, Session 2010/11, London: Stationery Office.

Mullan, D. (1997) Eyewitness Bloody Sunday, Dublin: Wolfhound Press.

Murphy, M. (2000) 'Northern Ireland Policing Reform and the Intimidation of Defense Lawyers', Fordham Law Review, 68 (5): 1877-1933.

Northern Ireland Office (2010a) Police (Northern Ireland) Act 2000 - Review of Temporary Recruitment Provisions, Consultation Paper, Belfast: Northern Ireland Office.

Ó Dúlacháin, C. (2004) Address to Joint Committee on Justice, Equality, Defence and Women's Rights, Sub-Committee on the Barron Report, Oireachtas, 18 February.

Olsen, T., Payne, L., and Reiter, A. (2010) 'At What Cost? The Political Economy of Transitional Justice', Taiwan Journal of Democracy, 6(1): 165184.

O’Rawe, M. (2003) 'Transitional Policing Arrangements in Northern Ireland: The Can't and Won't of the Change Dialectic', Fordham International Law Journal, 26(4): 1015-73.

Owers Report (2011) Review of the Northern Ireland Prison Service: Conditions, management and oversight of all prisons, Belfast: Department of Justice. 
Patten Report (1999) A New Beginning: Policing in Northern Ireland, Report of the Independent Commission on Policing for Northern Ireland, Belfast, available from http://cain.ulst.ac.uk/issues/police/patten/patten99.pdf

Prison Service (2010) Progress Report on the Diversity Action Plan, Belfast: Northern Ireland Prison Service.

Robins, J. (2010) 'Bloody Sunday: The Verdict', New Law Journal, 160 (7424) July. http://www.newlawjournal.co.uk/nlj/content/bloody-sunday-verdict

Rolston, B. (2000) Unfinished Business: State Killings and the Quest for Truth, Belfast: Beyond the Pale Publications.

Rolston, B. and Scraton, P. (2005) 'In the Full Glare of English Politics: Ireland, Inquiries and the British State', British Journal of Criminology 45 (4): 547-564.

Rowthorn, R. and Wayne, N. (1988) Northern Ireland: The Political Economy of Conflict, Cambridge: Polity.

Saville Report (2010) Report of the Bloody Sunday Inquiry, London: Stationery Office.

Sear, C. (2011) Investigatory Inquiries and the Inquiries Act 2005, London: House of Commons Library.

Sim, J. and Thomas, P. (1983) 'The Prevention of Terrorism Act: Normalising the Abnormal', Journal of Law and Society, 71.

Simpson, A. (2010) Duplicity and deception: policing the twilight zone of the troubles, Dingle, Co. Kerry: Brandon.

Smithwick

Tribunal

http://www.smithwicktribunal.ie/smithwick/HOMEPAGE.html 
Stevens Report (2003) Stevens Enquiry Overview and Recommendations,

Sutton, M. (1994) Bear in Mind these Dead: An Index of Deaths from the Conflict in Ireland 1969-1993, Belfast: Beyond the Pale Publications.

Thomas, P. (2003) 'Emergency and Anti-Terrorist Powers, 9/11: USA and UK’, Fordham International Law Journal, 26: 1193-1233.

Tomlinson, M. (1994) 25 Years On: The Costs of War and the Dividends of Peace, Frank Cahill Memorial Lecture, Belfast: West Belfast Economic Forum.

Tomlinson, M. and Kelly, G. (2011) Response to Northern Ireland's Draft Budget, Belfast. http://bit.ly/AtiE1f

Treacy, S. (2009) Pat Finucane: His Life and His Legacy, 52-56, London:

British and Irish Human Rights Watch. http://www.birw.org/

Vaughan, B. and Kilcommins, S. (2008) Terrorism, Rights and the Rule of Law: Negotiating Justice in Ireland. Cullompton: Willan

World Bank (2011) World Development Report 2011: Conflict, Security, and Development, Washington: World Bank.

Notes

1 HC Debate (1992-3) 230, col. 483-550.

2 Robert Hamill a Catholic construction worker, was attacked by a group of Protestants in Portadown town centre while walking home after a night out with two of his cousins. He died in hospital eleven days later. He was attacked in full view of four police officers, one of whom was a 'very experienced' Reserve Constable who allegedly colluded with one of the perpetrators in destroying evidence.

3 The Orange Order, founded in 1796, exists to promote Protestantism and is closely linked to Unionist political parties seeking to maintain Northern Ireland's position within the United Kingdom. 
4 The residents' account of the Drumcree dispute is dedicated to Rosemary Nelson who was killed on $15^{\text {th }}$ March 1999 by a bomb attached to her car (see Garvaghy Residents 1999).

5 An alternative explanation for the fire is given in chapter 4 of Simpson (2010). Duplicity and deception: policing the twilight zone of the troubles. Dingle, Co. Kerry, Brandon.

6 Baha Mousa was one of seven men detained by members of the British Army in Iraq in 2003. The men were handcuffed, subjected to hooding and kept in stress positions in extreme heat. They were repeatedly assaulted. Baha Mousa died after a violent assault and was found to have 93 external injuries (Gage Report 2011).

7 Examples include the shooting of Peadar Heffron and the murders of Stephen Carroll and Ronan Kerr. 